\title{
Comparative Evaluation of Energy and Exergy Performances of R22 and its Alternative R407C, R410A and R448A Refrigerants in Vapor Compression Refrigeration Systems
}

\author{
Mehmet ALTINKAYNAK, Engin OLGUN, Arzu ŞENCAN ŞAHİN* \\ ${ }^{1}$ Isparta University of Applied Sciences, Faculty of Technology, Department of Mechanical Engineering, 32260, \\ Isparta/TURKEY \\ arzusencan@isparta.edu.tr
}

Received/Gelis: 15.05 .2019

Accepted/Kabul: 09.07.2019

\begin{abstract}
One of the important parameters for cooling systems is the choice of refrigerant. Refrigerants used in cooling systems damage the atmosphere and cause global warming. For these reasons, alternative refrigerants which are not harmful to the environment and atmosphere have been used. In this study, the performance and exergy efficiency of R407C, R410A and R448A refrigerants which are alternative to R22 refrigerant in vapor compression refrigeration system were theoretically calculated. Engineering equation solver (EES) has been used for the thermodynamic analysis. The highest COP and exergy efficiency values were achieved in the system operating with refrigerant R22. The highest COP and exergy efficiency values after R22 fluid were determined in the system operating with R448A refrigerant. For different evaporator temperatures, the COP values of the R22 system vary between 2.7 and 2.81 . The COP values of the R448A system vary between 2.5 and 2.63 . The exergy efficiency of the system operating with R22 varies between $\% 39.4$ and \%52.2. The exergy efficiency of the system operating with R448A varies between \%36.6 and $\% 48.8$. R448A instead of R22 are found to be replacement refrigerants among other alternatives refrigerants as a result of the analysis.
\end{abstract}

Keywords: Refrigeration, R22, R407C, R410A, R448A, Coefficient of Performance.

\section{R22 ve Alternatifleri R407C, R410A ve R448A Soğutkanlarının Buhar Sıkıștırmalı Soğutma Sistemlerindeki Enerji ve Ekserji Performanslarının Karşılaştırmalı İncelenmesi}

\begin{abstract}
Öz: Soğutma sistemleri için önemli parametrelerden biri soğutucu akışkanın seçimidir. Soğutma sistemlerinde kullanılan soğutucu akışkanlar atmosfere zarar vermekte ve küresel 1sınmaya sebep olmaktadır. Bu sebeplerden dolayı, çevreye ve atmosfere zararı olmayan alternatif soğutucu akışkanlar kullanılmaya başlanmıştır. Bu çalışmada, R22 soğutucu akışkanına alternatif olan R407C, R410A ve R448A soğutucu akışkanlarının buhar sıkıştırmalı soğutma sistemindeki performansları ve ekserji verimleri teorik olarak hesaplanmıştır. Termodinamik analizler için Engineering Equation Solver (EES) programı kullanılmıştır. En yüksek COP ve ekserji verimi değerlerine R22 soğutkanı ile çalışan sistemde ulaşılmıştır. R22 akışkanından sonraki en yüksek COP ve ekserji verimleri R448A soğutucu akışkanı ile çalışan sistemde tespit edilmiştir. Farklı evaporatör sıcaklıkları için, R22 sisteminin COP değerleri 2.7 ile 2.81 arasında değişmektedir. R448A sisteminin COP değerleri 2.5 ile 2.63 arasında değişmektedir. R22 ile çalıșan sistemin ekserji verimliliği \% 39 ile \% 52 arasında değişmektedir. R448A ile çalışan sistemin ekserji verimliliği \% 36 ile\% 48 arasında değişmektedir. Analizler sonucunda diğer alternatif soğutkanlar arasında R448 soğutkanının R22 soğutkanı yerine kullanılabileceği görülmüştür.
\end{abstract}

Anahtar kelimeler: Soğutma, R22, R407C, R410A, R448A, Performans katsay1sı. 


\section{Introduction}

People have always made great strides in the field of cooling to protect their food and beverages, to live comfortably and to keep their products more healthy by developing new technologies to meet their needs [1]. This process that develops in the field of air conditioning and cooling increases the energy demand of such systems. This increasing in energy demand on greenhouse gas emission negatively [2]. In addition, it has been determined that the refrigerants penetrate the ozone layer. In other words, it is understood that the ozone layer that protects our world from harmful ultraviolet rays is destroyed by the refrigerants and causes the increase of the world's temperature by showing global warming effect [3].

In the literature, some studies have been done on R22 and vapor compression refrigeration systems working with alternative refrigerants. Dalkilic and Wongwises have compared the performance of vapor compression refrigeration system by using various alternative refrigerants. They used R32, R134a, R12, R22 as refrigerant. They investigated the performance coefficient and power consumption for different evaporator temperatures [4]. Sagia and Rakopoulos used alternative refrigerant fluids for ground source heat pump. Alternative refrigerants instead of R22 were used. Performance coefficients were investigated by using alternative refrigerants in a single-stage vapor compression system without subcooling and superheating [5]. Vaghelo performed comparative evaluation of an automobile air-conditioning system using R134a and its alternative refrigerants. R290, R600a, R407C, R410A, R404A, R152a and R1234yf were used as refrigerants [6]. Mohanraj et al. performed a comparative performance analysis in automobile air conditioning system using refrigerants formed by hydrofluorocarbons (HFC) and their mixtures. Also, technical difficulties of refrigerants are discussed [7]. Harby K. carried out review study hydrocarbons and their mixtures as alternatives to environmental unfriendly halogenated refrigerants [8]. Devecioglu et al. studied vapor compression air conditioning systems using R442A refrigerant instead of R22. In the experimental study, cooling capacity, COP and compression ratio were determined. It is concluded that R442A may be an alternative to R22 [9]. Demircioglu performed energy and exergy analyzes in heat pump systems using R22 and its alternatives R407C and R410A refrigerants [10]. Ergun et al. carried out performance analysis of R438a and R417a refrigerants as an alternative to R22 in cooling systems. R438A was found out to have better COP values. [11]. Mota-Babiloni et al. made an experimental comparison for using R448A instead of R404A in refrigeration systems. According to their study, R448A has smaller cooling capacity, but has higher COP value and smaller energy consumption. They said R448A is a refrigerant which was energy efficient alternative to R404A with lower GWP [12]. Mendoza-Miranda et al. made evaluation of R448A and R450A as low-GWP alternatives for R404A and R134a using a micro-fin tube evaporator model. They were measured experimental data at different operating conditions [13]. Sethi et al. made an experimental study about R404A replacements for commercial refrigeration. They said that R404A has high GWP value and R448A and R455A the most suitable refrigerants for replacements. R448A matches the capacity with 4 to $8 \%$ higher efficiency compared to R404A. R448A provided 9 to $20 \%$ energy savings for supermarket refrigeration systems [14]. Detailed studies on energy and exergy analysis of cooling systems using alternative refrigerants can be found in the literature [15-24]. Park et al. performances of two pure hydrocarbons and seven mixtures composed of propylene, propane, HFC152a, and dimethylether were measured to substitute for HCFC22 in residential air-conditioners and heat pumps [15]. La Rocca and Panno performed experimental analysis comparing the performance of a vapor compression refrigerating unit operating with R22, and its performance in comparison to a new HFC fluid [16]. Park and Jung carried out thermodynamic performance of HCFC22 alternative refrigerants for residential airconditioning applications [17]. Bolaji investigated the performance of R22 and its ozone-friendly R404A and R507 in a window air conditioner [18]. Han et al. carried out performance study on R32/R125/R161 as an alternative refrigerant to R407C [19]. Venkataiah and Rao made analysis of alternative refrigerants to $\mathrm{R} 22$ for air-conditioning applications for various evaporating 
temperatures [20]. Joudi and Al-Amir investigated performance of residential air conditioning systems using R22 and alternatives R290, R407C, R410A [21]. Karagoz et al. investigated the possibilities of using R134a as a working fluid to replace R22 for vapor compression heat pumps [22]. Chen carried out performance and environmental characteristics of R410A and R22 residential air conditioners [23]. Park et al. investigated experimental performance of R432A to replace R22 in residential air-conditioners and heat pumps [24].

In this study, the energy and exergy analysis of the system were made in case of using ozone depleting refrigerants such as R407C and 410A instead of R22 with some changes in system for air conditioning devices. In addition, the performance of the vapor compression refrigeration system using R448A refrigerant similar the characteristic of R22 refrigerant is compared with other refrigerant systems.

\section{Vapor Compression Cooling System and Thermodynamic Analysis}

In a vapor compression refrigeration cycle, the refrigerant enters the compressor as saturated steam and the refrigerant is compressed to the condenser pressure. The refrigerant then enters the condenser as superheated steam. It emerges as saturated liquid by giving heat to the environment.

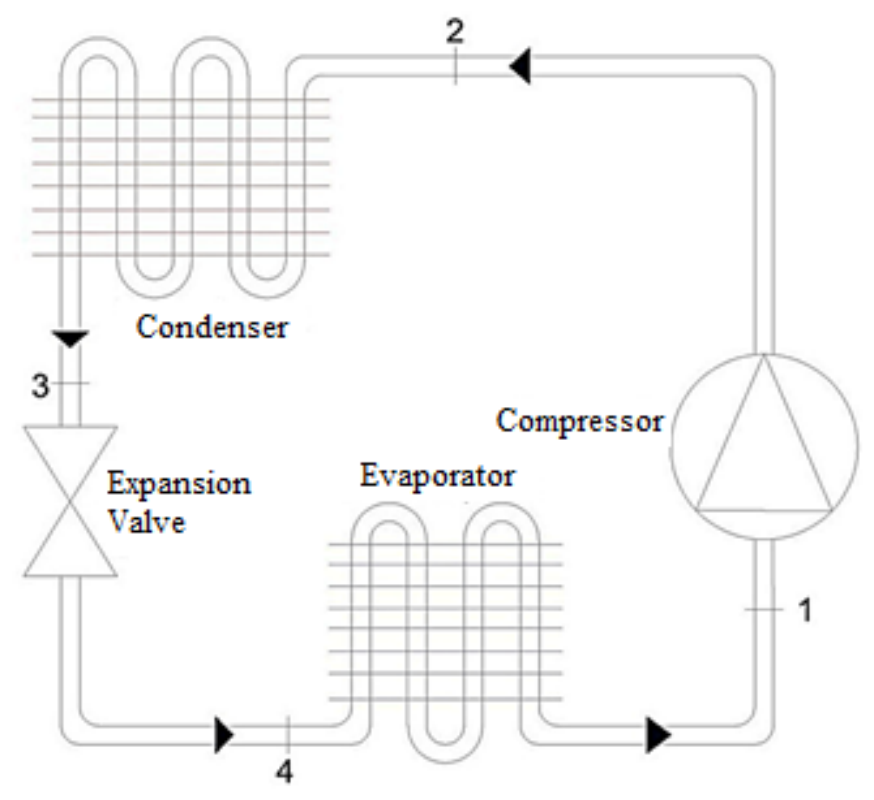

Figure 1. Vapor compressing cooling cycle

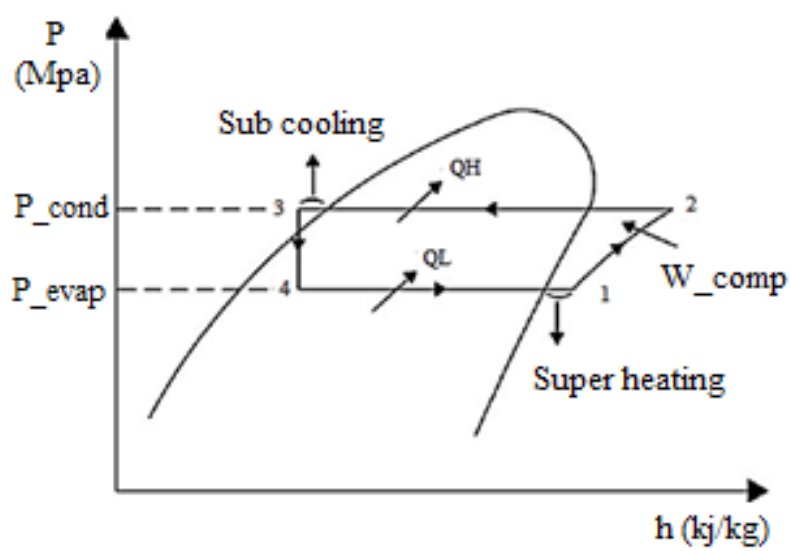

Figure 2. P-h diagram of vapor compressing cooling cycle with superheating and subcooling 
The refrigerant is passed through the expansion valve until the evaporator pressure is reduced. The refrigerant then enters the evaporator and completely evaporates by taking heat from the cooled environment. The refrigerant exits the evaporator as saturated vapor and re-enters the compressor to complete its cycle. [25]. Figure 1 shows schematically a vapor compressing cooling system used in this study. Figure 2 shows the P-h diagram of the system.

In this study, R407C, R410A and R448A refrigerants are used as an alternative to R22 in vapor compression refrigeration system. Some properties of the refrigerants used are given in Table 1.

Table 1. Some properties of used refrigerants

\begin{tabular}{|c|c|c|c|c|c|c|}
\hline Refrigerant & Compound & $\begin{array}{c}\text { Global } \\
\text { Warming } \\
\text { Potential } \\
\text { (GWP) }\end{array}$ & $\begin{array}{c}\text { Ozone } \\
\text { Depleting } \\
\text { Potential } \\
\text { (ODP) }\end{array}$ & $\begin{array}{c}\text { Critical } \\
\text { Temp. }\left({ }^{\circ} \mathrm{C}\right)\end{array}$ & $\begin{array}{c}\text { Critical } \\
\text { Pressure } \\
\text { (bar) }\end{array}$ & $\begin{array}{c}\text { Flammability } \\
\text { Level }\end{array}$ \\
\hline $\mathrm{R} 407 \mathrm{C}$ & R32, R125, R134a & 1774 & 0 & 86.03 & 46.29 & Not Flammable \\
\hline $\mathrm{R} 410 \mathrm{~A}$ & R32,R125 & 2088 & 0 & 71.35 & 49.02 & Not Flammable \\
\hline $\mathrm{R} 448 \mathrm{~A}$ & $\begin{array}{l}\text { R32, R125, R134a, } \\
\text { R1234ze, R1234yf }\end{array}$ & 1387 & 0 & 83.7 & 46.6 & Not Flammable \\
\hline R22 & Single component & 1810 & 0.055 & 96.15 & 49.9 & Not Flammable \\
\hline
\end{tabular}

In this study, the energy and exergy analysis of the vapor compression refrigeration system were carried out using the design parameters in Table 2. Engineering Equation Solver (EES) program was used in the analysis.

Table 2. Design parameters

\begin{tabular}{ll} 
Cooling Capacity, $\dot{Q}_{E}$ & $10 \mathrm{~kW}$ \\
Condenser Temperature, $\mathrm{T}_{\mathrm{K}}$ & $30^{\circ} \mathrm{C}$ \\
Evaporator Temperature, $\mathrm{T}_{\mathrm{E}}$ & $-9^{\circ} \mathrm{C}$ with $0{ }^{\circ} \mathrm{C}$ \\
Superheating Temp., $\Delta \mathrm{T}_{\mathrm{AK}}$ & $5^{\circ} \mathrm{C}$ \\
Subcooling Temp., $\Delta \mathrm{T}_{\mathrm{AS}}$ & $5^{\circ} \mathrm{C}$ \\
Ambient Temp., $\mathrm{T}_{0}$ & $25^{\circ} \mathrm{C}$ \\
\hline
\end{tabular}

Thermodynamic analysis of the system is made according to the first and second law of thermodynamics. In the energy and exergy analysis of the vapor compression refrigeration system, the condenser, evaporator and compressor loads are written as follows considering the cycle points shown in Figure 1 and Figure 2:

Compressor:

$$
\dot{W}_{\text {Comp }}=\dot{m}\left(h_{2}-h_{1}\right)
$$

Condenser:

$$
\dot{Q}_{C}=\dot{m}\left(h_{3}-h_{2}\right)
$$

Evaporator:

$$
\dot{Q}_{E}=\dot{m}\left(h_{4}-h_{1}\right)
$$

Coefficient Performance (COP)

$$
\mathrm{COP}=\frac{\dot{Q}_{E}}{\dot{W}_{\text {Comp }}}
$$


Exergy of the flow is calculated as follows:

$$
\dot{E} \mathrm{x}=\dot{m}\left[\left(\mathrm{~h}-h_{0}\right)-T_{0}\left(s-s_{0}\right)\right]
$$

Exergy destruction of Compressor:

$$
\dot{E} x_{\text {dest,Comp }}=\dot{E} x_{1}-\dot{E} x_{2}+\dot{W}_{\text {Comp }}
$$

Exergy destruction of Condenser:

$$
\dot{E} x_{d e s t, \text { cond }}=\dot{E} x_{2}-\dot{E} x_{3}-\dot{Q}_{C}\left(1-\frac{T_{0}}{T_{K}}\right)
$$

Exergy destruction of Evaporator:

$$
\dot{E} x_{d e s t, E v a p}=\dot{E} x_{4}-\dot{E} x_{1}+\dot{Q}_{E}\left(1-\frac{T_{0}}{T_{E}}\right)
$$

Exergy destruction of Expansion Valve:

$$
\dot{E x_{d e s t, E x p}}=\dot{E} x_{3}-\dot{E} x_{4}
$$

Exergy efficiency of the system is calculated as follows:

$$
\eta_{E x}=\frac{\dot{E} x_{1}-\dot{E} x_{4}}{\dot{W}_{\text {Comp }}}
$$

\section{Research Findings}

In this study, energy and exergy analysis of a vapor compression refrigeration system using R407C, R410A and R448A fluids, which is an alternative to R22, was performed. The Engineering Equation Solver (EES) is used in the analysis. Figure 3 shows variation of COP values with different evaporator temperatures for all refrigerants. As shown in Figure 3, the COP value of the system increases with increasing evaporator temperature for the constant condensation temperature of $30{ }^{\circ} \mathrm{C}$ and evaporation temperatures ranging from $-9{ }^{\circ} \mathrm{C}$ to $0{ }^{\circ} \mathrm{C}$. The $\mathrm{COP}$ values of R22 refrigerant system are higher than those of other refrigerants. The COP values of the R22 system vary between 2.7 and 2.81. In comparative graph of COP values, R22 refrigerant is followed by R448A refrigerant which has lower GWP compared to other refrigerants. The COP values of the R448A system vary between 2.5 and 2.63 .

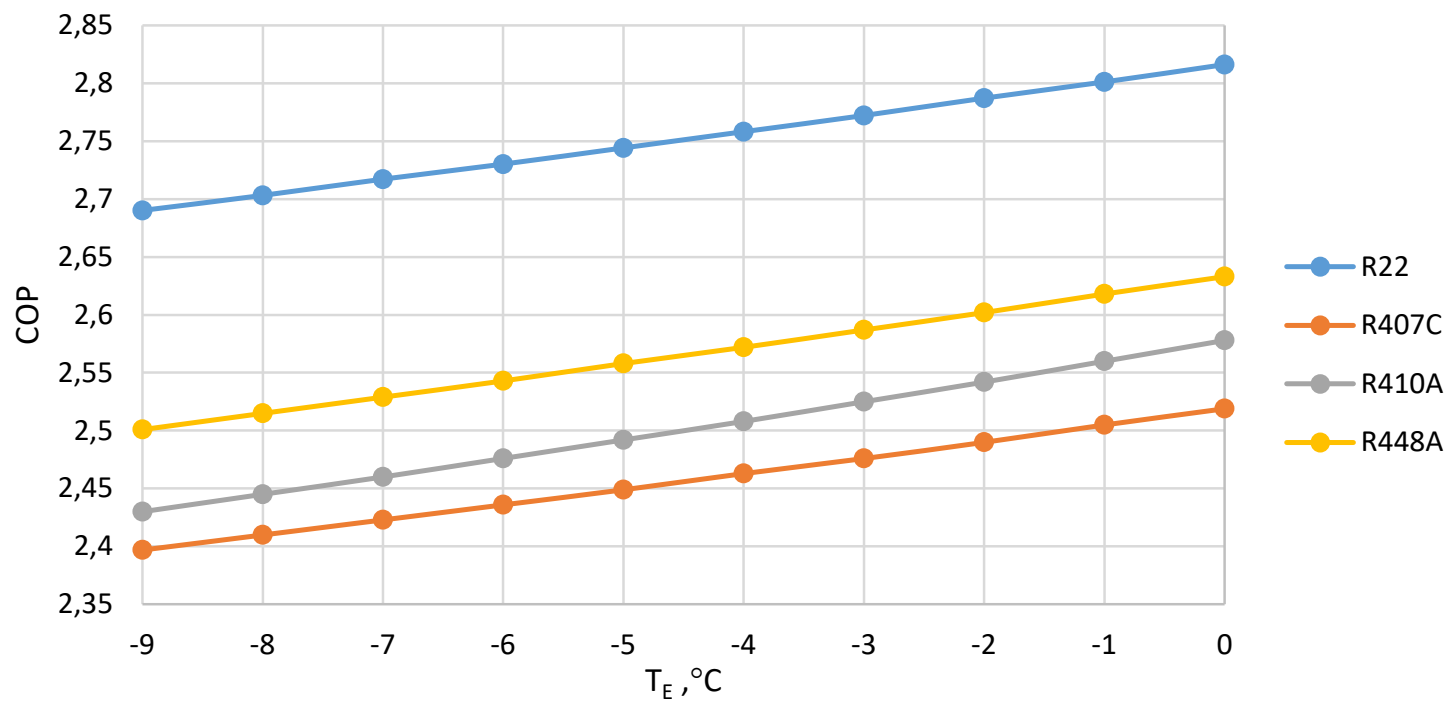

Figure 3. Effect to COP of evaporator temperature 

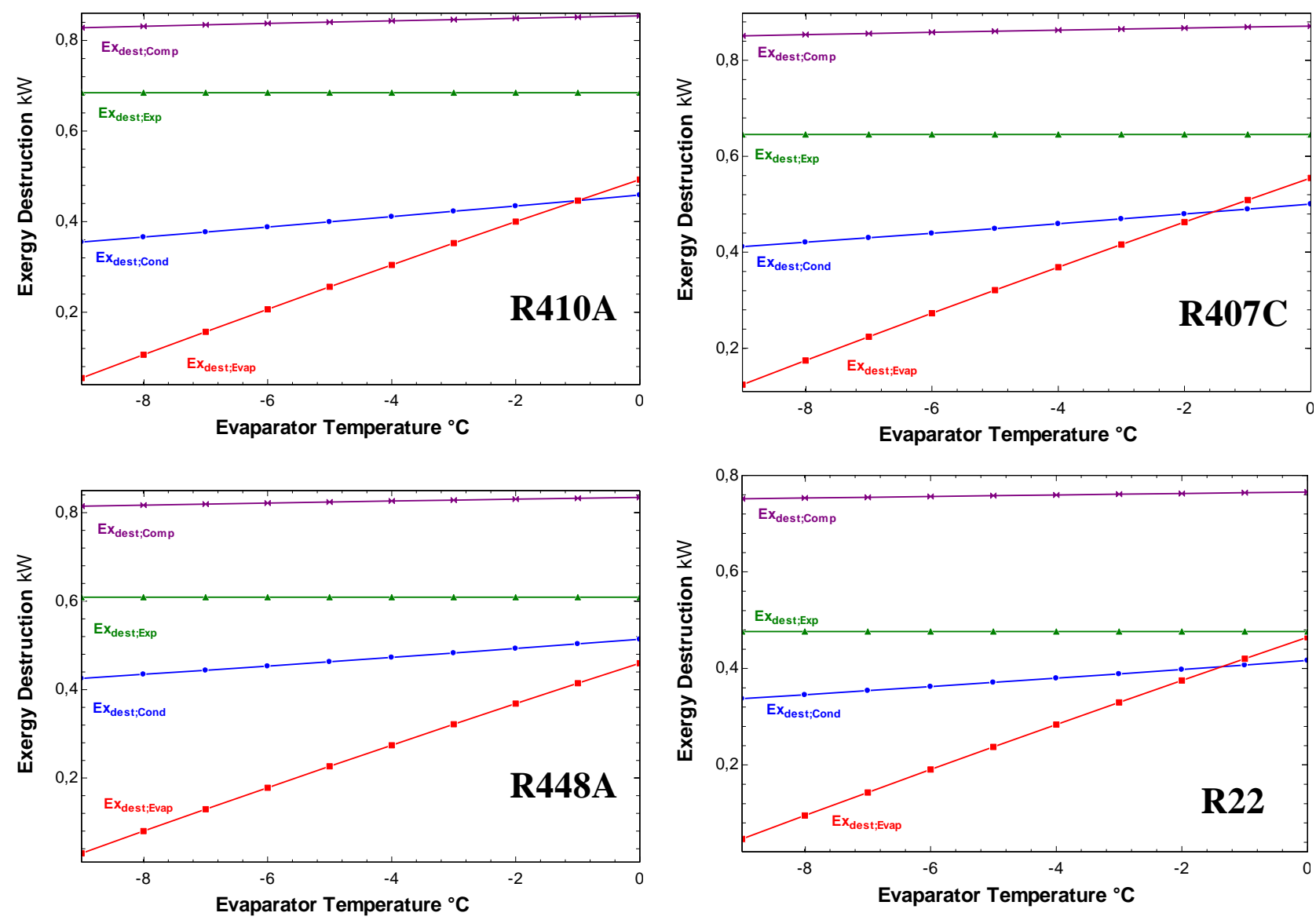

Figure 4. Exergy destruction of the system components with evaporator temperature for each refrigerant

Figure 4 shows exergy destruction of the system components with different evaporator temperature for each refrigerant. As the evaporator temperatures increased, it was observed that exergy destruction of each system component increased.

\section{Total Exergy Destruction}

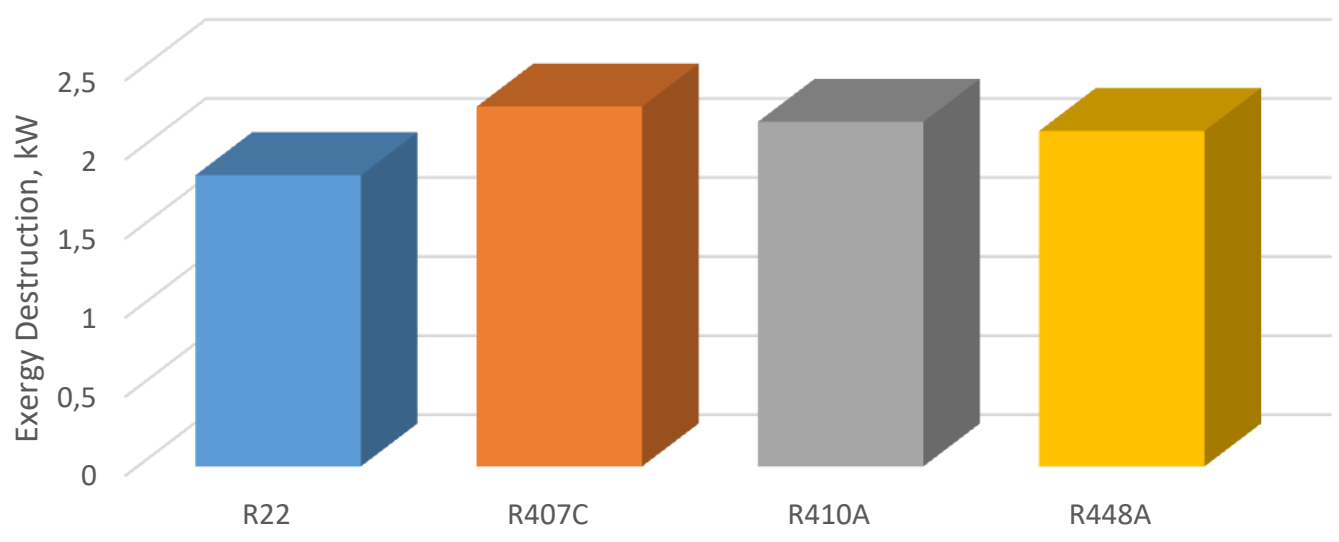

Figure 5. Total exergy destruction of vapor compression refrigeration system for each refrigerant

Figure 5 shows the total exergy destruction of the vapor compression refrigeration system for each refrigerant. The total exergy destruction of the system operating with refrigerants R22, R448A, 
$\mathrm{R} 410 \mathrm{~A}$ and $\mathrm{R} 407 \mathrm{C}$ were $1.842 \mathrm{~kW}, 2.122 \mathrm{~kW}, 2.179 \mathrm{~kW}$ and $2.276 \mathrm{~kW}$, respectively. The total exergy destruction of the system operating with R22 is the lowest. The next lowest exergy destruction is that of the system operating with R448A.

Figure 6 shows the changes in exergy efficiencies by changing the evaporator temperature for all refrigerants. As shown in Figure 6, the exergy efficiency of the system decreases as the evaporator temperature increases.

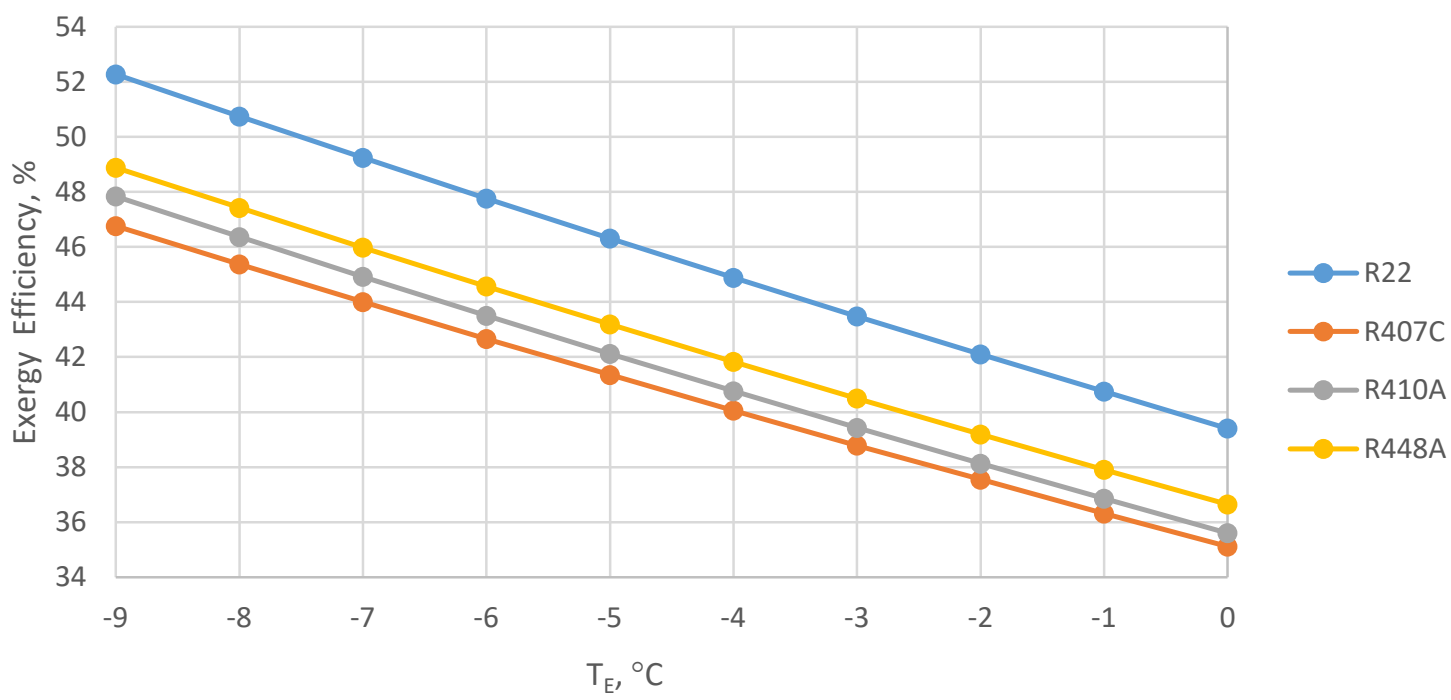

Figure 6. Effect to exergy efficiency of evaporator temperature

Exergy efficiency values of R22 refrigerant system are higher than other refrigerant system. The exergy efficiency of the system operating with R22 varies between \%39.4 and \%52.2. Exergy efficiency of R22 refrigerant system was followed by exergy efficiency values of R448A refrigerant system. The exergy efficiency of the system operating with R448A varies between $\% 36.6$ and $\% 48.8$.

\section{Results}

ODP and GWP value have become the most important criteria in the development of alternative refrigerants. In this study, performance and exergy analysis of the vapor compression refrigeration system is examined for 4 refrigerants (R22, R407C, R410A and R448A). COP and exergy efficiency values are computed using EES program.

COP value of the system increases with increasing evaporating temperature for a constant condensing temperature in the analysis. Considering the highest COP value, the widely used R-22 seems the best. For different evaporator temperatures, the COP values of the R22 system vary between 2.7 and 2.81. The COP values of the R448A system vary between 2.5 and 2.63. R448A $\mathrm{COP}$ value has a COP value very close to R-22 COP value.

The total exergy destruction of the system operating with R22 is the lowest $(1.842 \mathrm{~kW})$. The next lowest exergy destruction is that of the system operating with R448A $(2.122 \mathrm{~kW})$. The exergy efficiency of the system operating with R22 varies between \%39.4 and \%52.2. The exergy efficiency of the system operating with R448A varies between \%36.6 and \%48.8. R448A instead of $\mathrm{R} 22$ are found to be replacement refrigerants among other alternatives in this paper as a result of the analysis. 


\section{References}

[1]. Onat, A., İmal, M., İnan, A.T., "Investigation the Effects of Refrigerants on Ozone Layer and Alternative Refrigerants”, KSÜ Fen ve Mühendislik Dergisi, 2004, 7(1), In Turkish.

[2]. Sogut, M.Z., Karakoç, H., Kılkış, B., "Examination of Enviromental Performances of Refrigerants on the basis of Exergy Efficiency", 6. Uluslararası İleri Teknolojiler Sempozyumu (IATS'11), Elazığ, Türkiye, 16-18 May 2011, In Turkish.

[3]. Onat, A., "Investigation of the Effects of Refrigerants on Ozone Layer Investigation of the Effects of Cooling Fluids on Ozone Layer", Makine Eğitimi Yüksek Lisans Tezi, Marmara Üniversitesi Fen Bilimleri Enstitüsü,1994, In Turkish.

[4]. Dalkilic, A. S., \& Wongwises, S., "A performance comparison of vapour-compression refrigeration system using various alternative refrigerants", International Communications in Heat and Mass Transfer, 2010, 37(9): 1340-1349.

[5]. Sagia, Z., \& Rakopoulos, C., "Alternative refrigerants for the heat pump of a ground source heat pump system", Applied Thermal Engineering, 2016, 100: 768-774.

[6]. Vaghela, J. K., "Comparative evaluation of an automobile air-conditioning system using R134a and its alternative refrigerants", Energy Procedia, 2010, 109: 153-160.

[7]. Mohanraj, M., Jayaraj, S., \& Muraleedharan, C., "Environment friendly alternatives to halogenated refrigerants-A review", International Journal of Greenhouse Gas Control, 2009, 3(1): 108-119.

[8]. Harby, K., "Hydrocarbons and their mixtures as alternatives to environmental unfriendly halogenated refrigerants: An updated overview", Renewable and Sustainable Energy Reviews, 2017, 73: 1247-1264.

[9]. Devecioğlu, A. G., Oruç, V., Berk, U., \& Ender, S., "İklimlendirme sistemlerinde R22 yerine R442A kullanılmasının enerji parametrelerine etkisinin incelenmesi", Dicle Üniversitesi Mühendislik Fakültesi Dergisi, 2016, 7(3): 551-558.

[10]. Demircioğlu, A., "Theoretical investigation of performances of R22 and R407c and R410a which are substitutes for R22 in a heat pump", Yüksek Lisans Tezi, Gazi Üniversitesi Fen Bilimleri Enstitüsü,2010, In Turkish.

[11]. Ergün A., Gürel, A.E., Ceylan, İ., "Performance Analysis of R438a and R417a Refrigerants as an Alternative to R22 in Commercial Cooling Systems", Gazi Üniversitesi Fen Bilimleri Dergisi, 2018, 6(4): 824-833, In Turkish.

[12]. Mota-Babiloni, A., Navarro-Esbri, J., Peris, B., Molés, F., Verdú, G., "Experimental evaluation of R448A as R404A lower-GWP alternative in refrigeration systems", Energy Conversion and Management, 2015, 105: 756-762.

[13]. Mendoza-Miranda,J.,M., Mota-Babiloni,A., Navarro-Esbrí, J., "Evaluation of R448A and R450A as low-GWP alternatives for R404A and R134a using a micro-fin tube evaporator model", Applied Thermal Engineering, 2016, 98: 330-339.

[14]. Sethi, A., Pottker, G., Motta, S.Y., "Experimental evaluation and field trial of low global warming potential R404A replacements for commercial refrigeration", Science and Technology for the Built Environment, 2016, 22: 1175-1184.

[15]. Park, K. J., Seo, T., \& Jung, D., "Performance of alternative refrigerants for residential airconditioning applications", Applied Energy, 2007, 84: 985-991.

[16]. La Rocca, V., \& Panno, G., "Experimental performance evaluation of a vapour compression refrigerating plant when replacing R22 with alternative refrigerants", Applied Energy, 2011, 88: 2809-2815.

[17]. Park, K. J., \& Jung, D., "Thermodynamic performance of HCFC22 alternative refrigerants for residential air-conditioning applications”, Energy and Buildings, 2007, 39(6): 675-680. 
[18]. Bolaji, B. O., "Performance investigation of ozone-friendly R404A and R507 refrigerants as alternatives to R22 in a window air-conditioner", Energy and Buildings, 2011, 43(11): 31393143.

[19]. Han, X. H., Wang, Q., Zhu, Z. W., \& Chen, G. M., "Cycle performance study on R32/R125/R161 as an alternative refrigerant to R407C", Applied Thermal Engineering, 2007, 27(14-15): 2559-2565.

[20]. Venkataiah, S., \& Rao, G. V., "Analysis of alternative refrigerants to R22 for air-conditioning applications at various evaporating temperatures", International Journal of Engineering Research and Applications, 2014, 4(3): 39-46.

[21]. Joudi, K. A., \& Al-Amir, Q. R., "Experimental Assessment of residential split type airconditioning systems using alternative refrigerants to R-22 at high ambient temperatures", Energy Conversion and Management, 2014, 86: 496-506.

[22]. Karagoz, S., Yilmaz, M., Comakli, O., \& Ozyurt, O., "R134a and various mixtures of R22/R134a as an alternative to R22 in vapour compression heat pumps", Energy Conversion and Management, 2004, 45(2): 181-196.

[23]. Chen, W., "A comparative study on the performance and environmental characteristics of R410A and R22 residential air conditioners", Applied Thermal Engineering, 2008, 28(1): 1-7.

[24]. Park, K. J., Shim, Y. B., \& Jung, D., "Experimental performance of R432A to replace R22 in residential air-conditioners and heat pumps", Applied Thermal Engineering, 2009, 29(2-3): 597600.

[25]. Çengel, Y. A., Boles, M.A., “Termodinamik - Mühendislik Yaklaşımıyla”, Güven Bilimsel Yayınevi, İstanbul, 2012. 